\title{
Mood Moderates the Effect of Self-Generation During Learning
}

\author{
Julia Schindler ${ }^{1}$, Tobias Richter ${ }^{1}, \&$ Carolin Eyßer ${ }^{2}$ \\ ${ }^{1}$ University of Würzburg, Germany \\ ${ }^{2}$ University of Regensburg, Germany
}

Article received 09 March 2017 / revised 16 November / accepted 21 November / available online 18 December

\begin{abstract}
Generating information, compared to reading, improves learning and enhances long-term retention of the learned content. This so-called generation effect has been demonstrated repeatedly for recall and recognition of single words. However, before adopting generating as a learning strategy in educational contexts, conditions moderating the effect need to be identified. This study investigated the impact of positive and negative mood states on the generation effect with short expository texts. According to the dual-force framework (Fiedler, Nickel, Asbeck, \& Pagel, 2003), positive mood should facilitate generation by enhancing creative knowledge-based top-down processing (assimilation). Negative mood, however, should facilitate learning in the read-condition by enhancing critical stimulus-driven bottom-up processing (accommodation). In contrast to our expectations, we found no general generation effect but an overall learning advantage of read compared to generated texts. However, a significant interaction of learning condition and mood indicates that learners in a better mood recall generated texts better than learners in a more negative mood, whereas no mood effect was found when the texts were read. The results of the present study partially support the predictions of the dual-force framework and are discussed in the context of recent theoretical approaches to the generation effect.
\end{abstract}

Keywords: Generation effect, learning with expository texts, mood states 


\section{Introduction}

A common assumption is that learning is most effective when it is easy. However, research suggests that under certain conditions learning is more effective when learners intentionally make it more difficult by, for example, distributing learning sessions, interleaving topics and tasks, testing learned content, and generating knowledge (Bjork \& Bjork, 2011). The advantage of generated compared to read information in memory tasks (generation effect) has been investigated extensively (for a meta-analysis, see Bertsch, Pesta, Wiscott, \& McDaniel, 2007). In the classical generation paradigm (e.g., McDaniel, Waddil, \& Einstein, 1988; Slamecka \& Graf, 1978) participants read an associated word pair (PURR - CAT) or they complete a fragment of the target word (PURR - C ___ $_{-}$). In a subsequent learning test, memory for generated target words is better than for read words. Findings like this suggest that using generation in every-day learning situations might be beneficial. However, before adopting generation as a learning strategy in educational contexts, conditions moderating the generation effect such as learners' cognitive abilities, motivation, or mood states need further clarification.

Research on the impact of mood on information processing has demonstrated that positive and negative mood states serve a regulatory function in terms of processing depth, processing capacity, and processing strategies (for an overview see Bless \& Fiedler, 2005; Fiedler, 2001). Fiedler assumes that these mood states trigger one of two possible learning settings that should affect generation differently. The learning settings and their consequences for the efficiency of generation are described in Fiedler, Nickel, Asbeck, and Pagel's (2003) dual-force framework. The framework is based on Fiedler's assumptions that (1) cognitive processes usually contain the two components of conservation of perceived information (accommodation) and the generation of new information based on internal knowledge structures (assimilation) and (2) positive and negative mood states trigger two different learning settings that encourage either assimilation or accommodation. Positive mood is assumed to trigger an appetitive learning setting that encourages exploration and creative and elaborative top-down processes. In other words, positive mood should encourage assimilative processes as required in generating activities. Negative mood, however, is assumed to trigger an aversive learning setting that encourages critical stimulus-driven processes. Thus, negative mood should encourage accommodative bottom-up processes as primarily required in reading (see Fiedler, 2001).

Fiedler et al. (2003) conducted three experiments to test some of the framework's implications, but they primarily addressed mood-congruency effects in word learning (words congruent with a learner's mood are recalled better than non-congruent words). Hence, their results provide only little insight in the predicted mood-generation interaction with neutral verbal material such as expository texts, which are usually used in educational contexts. In an earlier study, Fiedler, Lachnit, Fay, and Krug (1992, Exp. 4) found that positive mood compared to neutral mood enhanced the generation effect for neutral word pairs as predicted by the dualforce framework, but a negative mood state was not induced. The aim of the present study was to further investigate the impact of positive and negative mood states on the generation effect with more complex and naturalistic learning material.

\section{The present study}

Slamecka and Graf's (1978) fragment-completion paradigm was adopted for short naturalistic texts from a psychology text book (Mazur, 2006). Participants read either complete or generated fragmented definitions containing a concept and its description (e.g., Spontanerholung =Das Wie_erau_tre_en einer zu_or ge_ösc_te_Rea_tio_, nachdem lä_ge_e Ze_t ohne wei_ere Kon_itio_ie_un_sdu_ch_än_e ver_tri_he_ist/ Spontaneous recovery $=$ Recurrence of an extinguished reaction, after some time has passed without further conditioning) after receiving a positive or negative mood induction. We used short definitions instead of one longer text to be able to generalize possible findings across texts while keeping the learning phase after the 
mood induction as short as possible. Also, short definitions such as those used in the present study are typical every-day learning contents in school and university. Hence, we assume that these minimalistic texts are suitable to test the dual-force framework for naturalistic learning material in a first attempt. Fragment completion was used because it has been found to induce the generation effect quite constantly in several studies with target words as learning material (see the meta-analysis by Bertsch et al., 2007) and to improve memory for fairy tales and narratives (e.g., Einstein, McDaniel, Bowers, \& Stevens, 1984; McDaniel, 1984; McDaniel \& Kerwin, 1987). We expected learners to use the sentence context and, if available, prior knowledge to infer the fragmented words in the generation condition, thereby encouraging the construction of an elaborated mental representation of the texts.

We expected to find a generation effect (better recall for generated compared to read definitions). Moreover, based on the dual-force framework, positive mood was expected to enhance recall in the generation condition, whereas negative mood was expected to enhance recall in the read condition.

\section{Methodology}

Participants were 55 undergraduates (48 psychology students) from the University of Kassel and one non-student participant (all native speakers of German). Ten participants were male and 46 were female with a mean age of $21.96(S D=3.46$; $\operatorname{Min}=18$; Max =36). All participants provided written informed consent.

In a first step, participants' prior knowledge on the to-be-learned topic was assessed via a computerized 20 -item classification task. They were presented with 10 concepts from the field of learning and behavior (e.g., post-reinforcement pause) and with 10 pseudo-concepts (e.g., comparative reinforcement). Participants were asked to indicate for each concept whether it belongs to the field of learning and behavior or not.

Positive mood $(n=28)$ or negative mood $(n=28)$ was induced via the computerized mood-induction procedure by Robinson, Grillon, and Sahakian (2012). Participants listened to happy or sad music via headphones. At the same time, they were presented with 60 emotionally charged statements from Velten (1968) (e.g., happy: I often feel great and motivated; sad: I often feel sad and depressed) and were asked to read them as referring to themselves.

After the mood induction, participants read or generated 32 psychological definitions (varied within subjects) in two 15 min sessions with 16 definitions each (paper and pencil format). The order of learning condition (generate-read vs. read-generate) was counterbalanced across participants. After the second learning session, participants completed a sociodemographic questionnaire (e.g., age, sex, native language, highest level of education). In the subsequent test phase, participants were asked to provide the description for each concept.

At the end of the experiment, participants in the negative mood-induction group received an additional positive mood induction, and participants in the positive mood-induction group received an additional neutral mood induction. Self-reported mood was assessed via three visual analogue scales (How happy are you?/How sad are you?/How depressed are you?) ranging from 1 to 100 at six measuring times during the experiment (Time 1: before the first mood induction; Time 2: after the first mood induction and prior to Learning Phase 1; Time 3: prior to Learning Phase 2; Time 4: prior to the test phase; Time 5: after the test phase; Time 6: after the final mood induction). 


\section{4. $\quad$ Results}

Self-reported mood measures from the sad and depressed-mood scales were inverted so that higher values indicated a better mood. Participants' answers in the learning test were coded by two independent raters. The maximum scores ranged from 2 to 3 points. For each definition, the proportion of accurate recall was calculated (i.e., achieved score divided by maximum score). Considering that inter-rater reliability was very high for proportion of accurate recall $(\operatorname{ICC}($ just $)=.95)$, we combined the ratings into one measure of recall accuracy (ranging from 0 to 1 with 1 indicating maximum score achievement). For mood measures (manipulation check) and rated accuracy of recall, we estimated Linear Mixed Models (LMM, Baayen, Davidson, \& Bates, 2008). All models were estimated and tested with the software packages lme4 (Bates et al., 2014) and lmerTest for R (Kutznetsova, Brockhoff, \& Christensen, 2014). All significance tests were based on a Type-I error probability of .05. One-tailed tests have been used for all directional hypothesis.

Mood measures (manipulation check). Six linear mixed models were estimated for each mood measure (happy, sad, depressed) as dependent variables to derive the simple main effects for mood induction at the six times of measurement during the experiment. Mood induction was included as a contrast-coded fixed effect $(-1=$ negative mood, $1=$ positive mood $)$ and measuring time in the form of five dummy-coded fixed effects (with Time 1 as the reference category). Intercepts were allowed to vary randomly between participants (random effects of participants).

As expected, for the happy mood measure, the simple main effects for mood induction were significant at Time $2(\beta=23.04 ; t(44)=9.50 ; p<.001)$, Time $3(\beta=7.13 ; t(44)=2.94 ; p<.01)$, Time $4(\beta=8.70 ; t(44)$ $=3.59 ; p<.001)$ and Time $5(\beta=7.39 ; t(44)=3.05 ; p<.01)$ indicating that participants' self-reported mood was significantly better in the positive than in the negative mood-induction group at all measuring times between the first and the final mood induction. At Time 6, participants self-reported mood was significantly lower in the positive mood-induction group after the final neutral mood induction compared to the negative mood-induction group, which had just received a final positive mood induction $(\beta=-8.70 ; t(44)=-3.59 ; p$ $<.001)$.

For the inverted sad mood measure, the simple main effects for mood induction were significant at Time $2(\beta=18.79 ; t(44)=6.78 ; p<.001)$, Time $3(\beta=8.63 ; t(44)=3.11 ; p<.01)$, Time $4(\beta=10.00 ; t(44)=$ $3.61 ; p<.001)$, and Time $5(\beta=7.38 ; t(44)=2.66 ; p<.01)$, and for the inverted depressed mood measure at Time $2(\beta=18.86 ; t(44)=5.98 ; p<.001)$, Time $3(\beta=7.59 ; t(44)=2.41 ; p<.05)$, Time $4(\beta=10.36 ; t(44)=$ $3.28 ; p<.01)$ and Time $5(\beta=5.63 ; t(44)=1.78 ; p<.05$; one-tailed). Both measures indicate that participants' self-reported mood was better in the positive than in the negative mood-induction group between Time 2 and Time 5 .

Figure 1 illustrates the differences in self-reported mood between both mood-induction groups at the six times of measurement for the three mood measures. Given the significant differences between both moodinduction groups at Time 2 to Time 5 for all three measures, we consider the mood induction to have been successful. 
a)

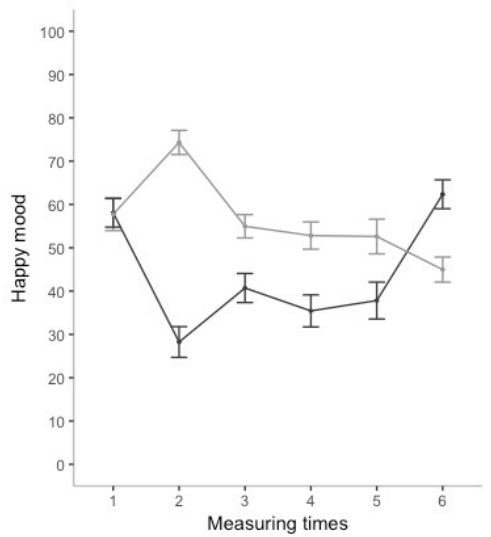

b)

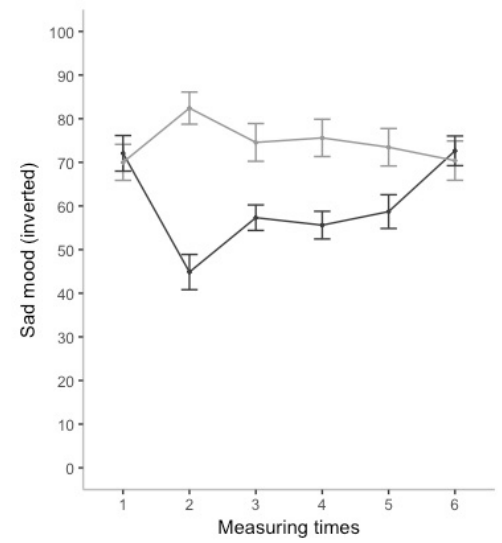

c)

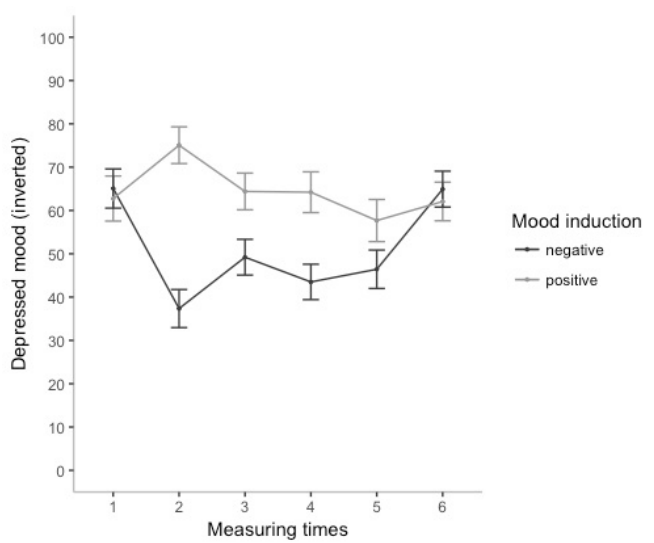

Figure 1. Mood measures for positive and negative mood-induction groups: Differences between moodinduction groups estimated at six measuring times for happy mood (a), inverted sad mood (b), and inverted depressed mood (c).

Rated recall accuracy. A linear mixed model was estimated for rated recall accuracy as dependent variable. Learning condition was included as a contrast-coded fixed effect $(-1=$ read, $1=$ generated $)$. Mood measures were combined for the three mood scales to include self-reported mood as a single fixed-effect predictor into the model. The learners' mood prior to Learning Phase 1 (Time 2) was used as a predictor for recall of definitions from Learning Phase 1, and mood prior to Learning Phase 2 (Time 3) was used as a predictor for definitions from Learning Phase 2 (centered around mean mood at Time 1 prior to first mood induction). In order to test whether it is adequate to integrate the three mood items at Times 2 und 3 into an integrated mood scale, we used confirmatory factor analysis (software package lavaan for R, Rosseel, 2012) with maximum likelihood to estimate and test a measurement model with one latent variable (mood) for each measuring time. The factor loadings for the same items at the two measuring times were set equal. In addition, the errors of pairs of the same items at the two times of measurement were allowed to covary, with the covariances of the three pairs of items set equal. This measurement model showed an acceptable model fit, $\chi^{2}=13.44(N=56, d f=9), p=0.078$, CFI $=.98$, TLI $=.96$, RMSEA $=.094$ (90\% confidence interval: .00 .19). Based on these results, it seems adequate to form an integrated mood scale.

To control for effects of prior knowledge, participants' proportion of correct responses in the priorknowledge test was included as a grand-mean centered fixed effect into the model. We expected better test performance for learners with high compared to low prior knowledge. To account for the different retention intervals of stimuli presented in Learning Phases 1 and 2, learning phase was included as another contrastcoded fixed effect $(-1=$ Learning Phase $1,1=$ Learning Phase 2$)$. We expected better recall for definitions from Learning Phase 2 than from Learning Phase 1 due to the longer retention interval for definitions from Learning phase 1. Finally, interaction terms between predictor variables were included in the model. The intercept was allowed to vary randomly between participants and definitions (random effects of participants and items).

Linear mixed model analysis revealed a significant main effect for learning phase $(\beta=0.02 ; t(40)=$ $2.45 ; p<.01$, one-tailed) indicating that definitions from Learning Phase 2 were recalled better than definitions from Learning Phase 1. Moreover, the analysis revealed a significant main effect for prior knowledge $(\beta=$ $0.07 ; t(40)=2.11 ; p<.05$, one-tailed), which was further characterized by a significant two-way interaction of learning condition and prior knowledge (see below). In contrast to our expectations, we found no generation effect but a learning advantage for read compared to generated definitions $(\beta=-0.04 ; t(40)=-5.09 ; p<.001)$, which was moderated by prior knowledge $(\beta=0.02 ; t(40)=2.42 ; p<.05)$ and $\operatorname{mood}(\beta=0.001 ; t(40)=1.85 ; p$ 
$<.05$, one-tailed). The simple slope of prior knowledge was significant for generated but not for read definitions. The higher the learners' prior knowledge, the better they recalled generated definitions (Figure 2). The effect of mood was also significant for generated but not for read definitions. As expected, learners in a better mood recalled generated definitions better than learners in a more negative mood (Figure 3 ).

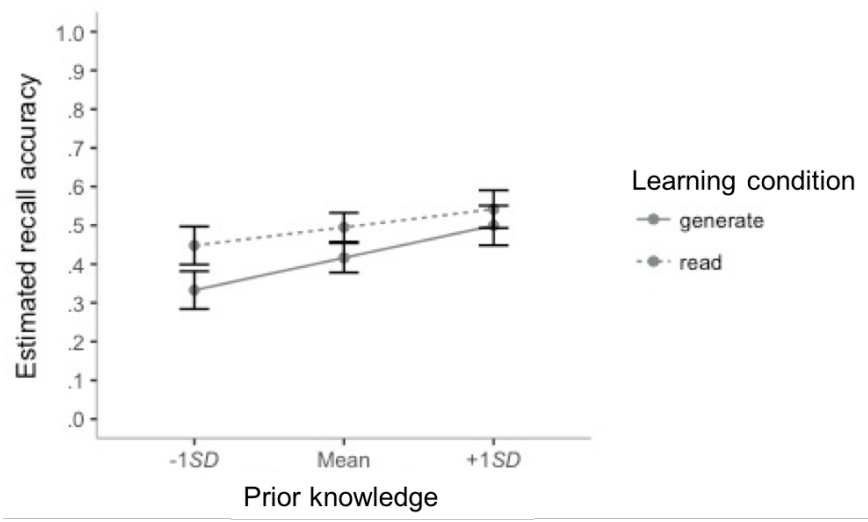

Figure 2. Estimated recall accuracy (proportions) for generated and read definitions: Simple slopes for prior knowledge and differences between learning conditions estimated at three different levels of prior knowledge.



Figure 3. Estimated recall accuracy (proportions) for generated and read definitions: Simple slopes for mood and differences between learning conditions estimated at three different levels of mood.

\section{Discussion}

The aim of the present study was to test the predictions derived from Fiedler et al.'s (2003) dual-force framework that positive mood benefits learning with generated texts, whereas negative mood benefits learning with read material. According to the framework, positive mood triggers an appetitive learning setting that encourages assimilative, i.e. creative and elaborate, top-down processes, which are central to generation. Consistent with this assumption, we found that learners in a better mood recalled generated definitions better than learners in a more negative mood. The finding that learners with higher prior knowledge recalled generated (but not read) definitions better than learners with lower prior knowledge further supports Fiedler et al.'s assumption that generation requires assimilative knowledge-based elaboration. 
Moreover, the dual-force framework assumes that negative mood triggers an aversive learning setting that encourages accommodative bottom-up processes, which are central to reading. However, we did not find negative mood to improve learning in the read condition. A possible explanation might be that most participants (fortunately) seem to have had a rather positive prevailing mood. Even after the participants' mood in the negative mood-induction group decreased significantly at Times 2 and 3 under the prevailing positive mood level, it increased to a more neutral mood level at Time 3 . Thus, the negative mood induction, although successful and persistent, might have been too weak to ensure a constantly aversive learning setting. Another, more likely explanation for the lack of negative mood influence, however, is that text comprehension (in contrast to single word reading) always requires certain knowledge-driven assimilative processes such as drawing inferences or establishing relations of coherence in order to establish a rich and coherent mental model of the text (Graesser, Millis, \& Zwaan, 1997; Van Dijk \& Kintsch, 1983). Consequently, it is not surprising that reading coherent texts benefits less from a negative mood state than reading single words. Given the different cognitive processes involved in word and text reading, differential implications should be derived from the dual-force framework for learning with words and more naturalistic texts.

An unexpected finding was the absence of an overall generation effect. In contrast to extant research demonstrating the beneficial effect of fragment completion on text memory (Einstein et al., 1984; McDaniel, 1984), learners in our study recalled read definitions better than generated definitions. A likely explanation is provided by McDaniel and Butler's (2010) contextual framework. They assume that learning difficulties such as generation are only desirable when they stimulate cognitive processing that is not stimulated by the material itself. They further assume that descriptive texts primarily encourage concept-specific processing at the word and proposition level (for a detailed explanation see McDaniel \& Einstein, 2005). Therefore, letter deletion, which is also assumed to encourage concept-specific processing, benefits memory for descriptive texts less than a task that stimulates relational processing (between propositions) such as reordering scrambled sentences (McDaniel, Einstein, Dunay, \& Cobb, 1986). According to the contextual framework, a relational processing task might have evoked the expected generation effect with the learning material used in our study.

The results of the present study need to be interpreted with its limitations in mind. First, we used a rather specific sample (primarily Psychology students). The dual-force framework, however, focuses on basal learning processes and, therefore, does not differentiate between different learner groups. Thus, we assume that our sample was as good as any to start with. Moreover, we used just one type of generation task and text material. Replicating the present results with different samples, generation tasks, and learning material would further corroborate our findings and conclusions on the moderating role of mood states for generation. This seems even more important given the absence of the expected overall generation effect. Considering that learning outcome is always the result of a complex interaction of learner characteristics, learning material, generation task, and criterial task requirements (contextual framework, McDaniel \& Butler, 2010), farreaching conclusions can only be drawn with caution from a single study. However, our study was the first attempt to test the dual-force framework for naturalistic texts and, thus, can be seen as a starting point for future research.

Despite these limitations, our findings have important implications for developing activities in applied educational contexts. Given that learners in a better mood benefit more from generation than learners in a bad mood, students who are in a bad mood momentarily or who suffer from constantly bad mood states such as depression or anxiety disorders might be at a disadvantage when it comes to generating activities in classroom settings. In contrast, our findings suggest that games or exercises that enhance the students' mood might be used systematically to enhance the benefits students gain from generation. 


\section{Keypoints}

6. Generation effect

- Learning with expository texts

- Mood states

\section{Acknowledgments}

The research presented in this article was supported by the Federal State of Hessen and its LOEWE research initiative Desirable Difficulties in Learning (LOEWE: Landes-Offensive zur Entwicklung wissenschaftlichökonomischer Exzellenz [state offensive for the development of scientific and economic excellence]). We thank our student assistants for assisting in coding the participants' answers. The publication of this article was funded by the German Research Foundation (DFG) and the University of Würzburg in the funding programme Open Access Publishing.

\section{References}

Baayen, R. H., Davidson, D. J., \& Bates, D. M. (2008). Mixed effects modeling with crossed random effects for subjects and items. Journal of Memory and Language, 59, 390-412. doi:10.1016/j.jml.2007.12.005

Bates, D., Maechler, M., Bolker, B., Walker, S., Christensen, R. H. B., \& Sigmann, H. (2014). Lme4: linear mixed-effects models using Eigen and S4 [Software]. R-package version 1.1-6. Retrieved from: http://cran.r-project.org/package=lme4

Bertsch, S., Pesta, B. J., Wiscott, R., \& McDaniel, M. A. (2007). The generation effect: A meta-analytic review. Memory \& Cognition, 35, 201-210. doi:10.3758/BF03193441

Bjork, E. L., \& Bjork, R. A. (2011). Making things hard on yourself, but in a good way: Creating desirable difficulties to enhance learning. In M. A. Gernsbacher, R. W. Pew, L. M. Hough, \& J. R. Pomerantz (Eds.), Psychology and the real world: Essays illustrating fundamental contributions to society (pp. 5664). New York: Worth.

Bless, H., \& Fiedler, K. (2005). Mood and the regulation of information processing and behavior. In J. P. Forgas (Ed.), Affect in social thinking and behavior (pp. 65-84). New York: Psychology Press.

Einstein, G. O., McDaniel, M. A., Bowers, C. A., \& Stevens, D. T. (1984). Memory for prose: The influence of relational and proposition-specific processing. Journal of Experimental Psychology: Learning, memory, and Cognition, 10, 133-143. doi:10.1037/0278-7393.10.1.133

Fiedler, K. (2001). Affective states trigger processes of assimilation and accommodation. In L. L. Martin \& G. L. Clore (Eds.), Theories of mood and cognition: A user's guidebook (pp. 85-98). Mahwah, NJ: Erlbaum.

Fiedler, K., Lachnit, H., Fay, D., \& Krug, C. (1992). Mobilization of cognitive resources and the generation effect. The Quarterly Journal of Experimental Psychology, Section A, 45, 149-171. doi:10.1080/14640749208401320

Fiedler, K., Nickel, S., Asbeck, J., \& Pagel, U. (2003). Mood and the generation effect. Cognition and Emotion, 17, 585-608. doi:10.1080/02699930302301 
Graesser, A. C., Millis, K. K., \& Zwaan, R. A. (1997). Discourse comprehension. Annual Review of Psychology, 48, 163-189. doi:10.1146/annurev.psych.48.1.163

Kuznetsova, A., Brockhoff, P. B., \& Christensen, R. H. B. (2014). lmerTest: tests for random and fixed effects for linear mixed effect models (lmer objects of lme4 package). R-package version 2.06. Retrieved from: http://cran.r-project.org/web/packages/lmerTest/index.html

Mazur, J. E. (2006). Lernen und Verhalten [Learning and behavior] (6th ed.). München, Germany: Pearson Studium.

McDaniel, M. A. (1984). The role of elaborative and schema processes in story memory. Memory \& Cognition, 12, 46-51. doi:10.3758/BF03196996

McDaniel, M. A., \& Butler, A. C. (2010). A contextual framework for understanding when difficulties are desirable. In A. S. Benjamin (Ed.), Successful remembering and successful forgetting: A Festschrift in honor of Robert A. Bjork (pp. 175-198). New York: Psychology Press.

McDaniel, M. A., \& Einstein, G. O. (2005). Material appropriate difficulty: A framework for determining when difficulty is desirable for improving learning. In A. F. Healy (Ed.), Experimental cognitive psychology and its applications (pp. 73-85). Washington, DC: American Psychological Association.

McDaniel, M. A., Einstein, G. O., Dunay, P. K., \& Cobb, R. E. (1986). Encoding difficulty and memory: Toward a unifying theory. Journal of Memory and Language, 25, 645-656. doi:10.1016/0749596X(86)90041-0

McDaniel, M. A., \& Kerwin, M. L. (1987). Long-term prose retention: Is an organizational schema sufficient? Discourse Processes, 10, 237-252. doi:10.1080/01638538709544674

McDaniel, M. A., Waddil, P. J., \& Einstein, G. O. (1988). A contextual account of the generation effect: A three-factor theory. Journal of Memory and Language, 27, 521-536. doi:10.1016/0749-596X(88)90023$\mathrm{X}$

Robinson, O., Grillon, C., \& Sahakian, B. (2012). The mood induction task: A standardized, computerized laboratory procedure for altering mood state in humans. Protocol Exchange, 10. doi:10.1038/protex.2012.007

Rosseel, Y. (2012). lavaan: An R package for structural equation modeling. Journal of Statistical Software, 48, 1-36. Retrieved in February 2017 from: http://www.jstatsoft.org/v48/i02/

Slamecka, N. J., \& Graf, P. (1978). The generation effect: Delineation of a phenomenon. Journal of Experimental Psychology: Human Learning and Memory, 4, 592-604. doi:10.1037/0278-7393.4.6.592

Van Dijk, T. A., \& Kintsch, W. (1983). Strategies of discourse comprehension. New York: Academic Press.

Velten, E. (1968). A laboratory task for induction of mood states. Behavioural Research and Therapy, 6, 473482. doi:10.1016/0005-7967(68)90028-4 
Schindler et al

\section{Appendix}

Table 1. Stimulus Material: Concepts and Descriptions in the Read and the Generate Condition

\begin{tabular}{|c|c|c|}
\hline No. & Concept & Description in the read condition \\
\hline 1 & Abergläubisches Verhalten & $\begin{array}{l}\text { Verhalten, das auftritt, weil ihm zu einem früheren } \\
\text { Zeitpunkt zufällig oder versehentlich ein Verstärker } \\
\text { folgte. }\end{array}$ \\
\hline & Superstitious behavior & $\begin{array}{l}\text { Behavior that occurs because it was - by chance or } \\
\text { accidentally - followed by a reinforcer before. }\end{array}$ \\
\hline 2 & Bestrafung Typ I & $\begin{array}{l}\text { Verhaltensreduktions-Methode, bei der einem } \\
\text { bestimmten Verhalten ein aversiver Reiz folgt. }\end{array}$ \\
\hline & Punishment type I & $\begin{array}{l}\text { Procedure for reducing behavior in which a specific } \\
\text { behavior is followed by an aversive stimulus. }\end{array}$ \\
\hline 3 & Diskrimination & $\begin{array}{l}\text { Das Lernen, auf einen Stimulus, nicht aber auf einen } \\
\text { anderen, ähnlichen, zu reagieren. }\end{array}$ \\
\hline & Discrimination & $\begin{array}{l}\text { Learning to respond to a specific stimulus but not to a } \\
\text { similar one. }\end{array}$ \\
\hline 4 & Diskriminativer Stimulus & $\begin{array}{l}\text { Beim operanten Konditionieren ein Stimulus, der } \\
\text { anzeigt, ob eine Reaktion zur Verstärkung führt. }\end{array}$ \\
\hline & Discriminative stimulus & $\begin{array}{l}\text { A stimulus that indicates if a reaction will be reinforced } \\
\text { in operant conditioning. }\end{array}$ \\
\hline
\end{tabular}

$5 \quad$ Fester Intervallplan

Fixed interval plan

$6 \quad$ Generalisierung

Verstärkungsplan, in dem die erste Reaktion nach einem festen Zeitintervall verstärkt wird.

Reinforcement plan in which the first reaction is reinforced after a fixed period of time.

Übertragung einer gelernten Reaktion von einem Stimulus auf einen anderen, ihm ähnlichen.

Generalization

Transfer of a conditioned response to one stimulus to another similar one.

$7 \quad$ Gesetz des Effekts

Law of effect

8 Habituation

Habituation

Reaktionen, denen angenehme oder befriedigende Reize folgen, werden verstärkt und zukünftig öfter stattfinden.

Reactions followed by pleasant or satisfying stimuli are reinforced and will occur more often afterwards.

Nachlassen der Stärke einer reflexartigen Reaktion nach wiederholter Präsentation des auslösenden Stimulus.

The intensity of a reflexive response to a specific stimulus decreases when the stimulus is presented repeatedly.

$9 \quad$ Konditionierter Inhibitor

Ein konditionierter Stimulus, der eine konditionierte Reaktion abschwächt oder verhindert.

Conditioned inhibitor

10 Konditionierter Verstärker

A conditioned stimulus that attenuates or prevents a conditioned response.

Ein ursprünglich neutraler Stimulus kann eine Reaktion durch wiederholte Paarung mit einem primären Verstärker stärken.

\section{Description in the generate condition}

Ve hal en, das auf ri t, weil ihm zu einem frü_ere_Zei_pun_t zu_äl_ig oder ver_ehen_lic_ein Ver_tär_er fol_te.

Ver_alte_sre_uktio_s-Met_ode, bei der einem bes_imm_en Ver_alte_ein ave_sive_ $\mathrm{R}$ iz fol_t.

Das Ler_en, auf einen Sti_ulu_, nicht aber auf einen an_eren, äh_li_hen, zu rea_ieren.

Beim ope an en Ko di io ieren ein Sti_ulu_, der an_eigt, ob eine Rea_tio_zur Ver_tär_ung füh_t t.

Ve_stä_ku_gsp_an, in dem die ers_e Rea tio nach einem fe te Zeiti ter all ver_tär_t wird.

Übe $t$ agun einer gele nte Reak ion von einem S_imu_us auf einen an_eren, ihm äh_lic_en.

Rea_tio_en, denen an_ene_me oder be riedi ende Rei e fol en, werden ver_tär_t und zu_ün_tig öf_er sta_t_inden.

Nac la sen der S är e einer re lexa ti en Rea_tio_nach wie_er_ol_er Prä_enta_ion des au_lö_en_en S_imu_us.

Ein ko di ionie ter Sti ulu , der eine ko_di_ionie_te Rea_tio_ab_ch_äc_t oder ver_inde_t.

Ein ur_prü_g_ic_neu_rale_S_imu_us kann eine Reak_io_durch wie_er_ol_e 
Conditioned reinforcer

11 Kontext-Interferenz

Context interference

12 Kontra-Imitation

Contra-imitation

13 Lerntransfer

Learning transfer

14 Löschungsresistenz

Resistance to extinction

15

Nachverstärkungspause

Post-reinforcement pause

Negative Bestrafung

Negative punishment

17 Negative Verstärkung

Negative reinforcement

18 Nichtkontingente

Verstärkung

Non-contingent

reinforcement

19 Primärer Verstärker

Primary reinforcer

20 Proaktive Interferenz
An originally neutral stimulus reinforces a reaction by being repeatedly paired with a primary reinforcer.

Situationsmerkmale, die das Lernen einer neuen Aufgabe erschweren, aber langfristig zu einer besseren Leistung führen können.

Situational characteristics that make learning of a new task more difficult but enhance performance in the long run.

Wenn jemand das Gegenteil des Verhaltens ausführt, das ein Modell vorgemacht hat.

If someone shows the opposite of the behavior which was demonstrated by a model.

Im motorischen Lernen die Auswirkung der Erfahrung mit einer Aufgabe auf die Performanz bei einer anderen Aufgabe.

In motor learning the impact of experience with a specific task on performing a different task.

Der Grad, in dem eine Reaktion anhält, wenn sie nicht länger verstärkt wird.

The extant that a reaction lasts when it is no longer reinforced.

Eine Reaktionspause, die bei festen Quotenplänen in der Regel nach jedem Verstärker eintritt.

A reaction pause that generally occurs after the presentation of each reinforcer in the context of a fixed ratio plan.

Verfahren zur Verhaltensreduktion, bei dem ein erwünschter Reiz beseitigt oder entzogen wird, wenn das Verhalten auftritt.

Procedure for reducing behavior in which an appetitive stimulus is removed or detracted after a specific behavior occurred.

Methode der Verhaltensstärkung, bei der ein aversiver Reiz beseitigt oder entzogen wird, wenn das Verhalten auftritt.

Procedure for reinforcing behavior in which an aversive stimulus is removed or detracted after a specific behavior occurred.

Die Verabreichung von Verstärkern zu zufälligen Zeitpunkten, unabhängig vom Verhalten.

Random presentation of reinforcers irrespective of the behavior.

Ein Verstärker, der naturgemäß jede Reaktion verstärkt, auf die er folgt.

A reinforcer that naturally reinforces each reaction that directly preceded the reinforcer.

Wenn zuvor erlernter Stoff das Erlernen neuer Inhalte beeinträchtigt.
Paa un mit einem pri äre Ver tär_er stä_ken.

Si_uatio_s_erk_ale, die das Le_nen einer ne en $\mathrm{Au}$ ga e er c were, aber la_g_ri_tig zu einer be_se_en Lei_tun_ füh_en können.

Wenn jemand das $\mathrm{Ge}$ en eil des Ve_ha_te_s au_füh_t, das ein Mo_ell vor_ema ht hat.

Im mo_oris_he_Le_nen die Au_wi_kun der $\mathrm{Er}$ ah un mit einer Auf abe auf die Pe_fo_ma_z bei einer an_ere_Au_ga_e.

Der G_ad, in dem eine Rea_tio_an_äl_, wenn sie nicht län e ver tär t wird.

Eine Rea tio spau e, die bei fes en Quo_en_lä_en in der Re_el nach je_em Ve_s_ärke_ei tri_t.

Ve fah en zur Ver al ens edu tion, bei dem ein er_üns_h_er Re_z z besei_ig_oder ent_oge_wird, wenn das Ver_al_en auf_ri_t.

Me_ho_e der Ve_hal_ens_tär_un_, bei der ein ave_si_er R_iz besei_ig_oder ent_oge wird, wenn das Ver al en auf ri t.

Die Ve_ab_eic_ung von Ve_s_ärke_n zu zu_äl_ige_Zei_pu_k_en, una_hän_ig vom Ver_al_en.

Ein Ver_tär_e_, der natu_ge_äßje_e Rea tio ver tär t, auf die er fo g

Wenn zu_or erle_n_er Sto_f das Er_erne ne_er Inha_te beei_trä_hti_t. 
Proactive interference

$21 \quad$ Retroaktive Interferenz

Retroactive interference

Sättigung

Saturation

Selbstverstärkung

Self-reinforcement

Shaping

Shaping

Spontanerholung

Spontaneous recovery

Teilnehmende Modellierung

Participating modeling

Transsituationalitätsprinzip

Principle of

transsituationality

28

Tropismus

Tropism

29

Überlernen

Overlearning

30 Variabler Quotenplan
When previously learned information hinders the learning of new contents.

Wenn die Präsentation von neuem Material die Erinnerung an früher Gelerntes beeinträchtigt.

When learning new information hinders the memory of previously learned information.

Eine Methode zur Verhaltensreduktion, bei der der Verstärker in solchen Mengen gegeben wird, dass er seine Wirksamkeit verliert.

Procedure for reducing behavior in which the reinforcer is presented repeatedly until its effectiveness decreases.

Eine Verhaltensmodifikations-Technik, bei der das Individuum seine eigenen Verstärker für angemessenes Verhalten liefert

Technique for modifying behavior in which the individual provides reinforcers for appropriate behavior on his/her own.

Eine Methode zum Erlernen einer neuen Verhaltensweise, bei der die zunehmenden Annäherungen an das erwünschte Verhalten verstärkt werden.

Procedure for learning a new behavior in which each behavior is reinforced that increasingly approaches the target behavior.

Das Wiederauftreten einer zuvor gelöschten Reaktion, nachdem längere Zeit ohne weitere Konditionierungsdurchgänge verstrichen ist.

Recurrence of an extinguished reaction, after some time has passed without further conditioning.

Eine Art des Modelllernens, bei der der Lernende das Verhalten des Modells bei jedem Behandlungsschritt nachahmt.

Kind of model learning in which the learner imitates the behavior of a model in each step of the treatment.

Ein Stimulus, der in einer Situation als Verstärker fungiert, wird auch in anderen Situationen als Verstärker dienen.

A stimulus that serves as reinforcer in one situation will also serve as a reinforcer in different situations.

Eine angeborene Bewegung eines ganzen Organismus als Reaktion auf einen spezifischen Stimulus.

A hereditary movement of a whole organism as a response to a specific stimulus.

Die fortgesetzte Übung einer Reaktion, nachdem die Leistung scheinbar perfekt ist.

Continuing with exercise after the performance is apparently perfect.

Ein Verstärkungsplan, bei dem ein Verstärker nach einer variablen und nicht vorhersehbaren Zahl von Reaktionen verabreicht wird.
Wenn die Prä en atio von ne em Ma_eria_die Eri_ne_un_an frü_e Ge ernte beei trä hti t.

Eine Me hode zur Ve hal ens edu tio, bei der der Ve_s_är_er in so che Me gen ge_ebe_wird, dass er seine $\overline{\mathrm{W}} \mathrm{i}{ }_{-} \mathrm{k} \_$am_eit ver iert.

Eine Ver_al_ens_odi_ikatio_s-Tec_ni_, bei der das In ivi uum seine eige en Ve_stä_ke_für ange_esse_es Ve_ha_te_ lie ert.

Eine Me ho e zum Erle ne einer ne en Ver_al_ens_eise, bei der die zu_eh_ende An ähe un en an das er ünsc te Ve_ha_te_ve_stä_k_werden.

Das Wie erau tre en einer zu or ge_ösc_te_Rea_tio_, nachdem lä_ge_e Ze_t ohne wei_ere

Kon_itio_ie_un_sdu_ch_än_e ver_tri_he ist.

Eine A_t des Mo_el_le_ne_s, bei der der Le ne de das Ve hal en des Mo el s bei je_em Beha_dlu_gs_ch_itt na_hah_t.

Ein S_imu_us, der in einer Si_uatio_als Ve $s$ är er fu gie $t$, wird auch in an ere Si_uatio_en als Ve_s_ä_ke_die_en.

Eine an_ebo_ene Be_egun_eines gan en Or ani mu als Rea tio auf einen spe_ifi_che_Sti_ulu_.

Die fo_tge_et_te Übu_g einer Rea_tio_, nachdem die Leis_un_scheinbar pe_fe_t ist.

Ein Ve_stä_kun_s_lan, bei dem ein Ve stä ke nach einer va iab en und nicht vor_erse_ba_en Za_lvon Rea_tio_en ve $a b$ eich wird. 
Schindler et al

Variable ratio plan

31

Vermeidung

Avoidance

32

Verteilte Übung

Distributed practice
A reinforcement plan in which a reinforcer is presented after a variable and not predictable number of reactions.

Eine Art der negativen Verstärkung, bei der durch eine bestimmte Reaktion ein aversiver Reiz vermieden wird.

Kind of negative reinforcement in which an aversive stimulus is avoided by a certain reaction.

Ein Übungsverfahren, in dem sich sehr kurze

Übungsphasen mit Ruhezeiten abwechseln.

Exercise technique in which very brief phases of exercise alternate with pauses.
Eine A t der ne ati en Ve stä kun, bei der durch eine bes_im_te Rea_tio_ein ave si er Re $z$ ver iede wird.

Ein Übu g ve fah en, in dem sich sehr kur e Übu g p ase mit Ru_ezei_en ab ech el

Notes. All definitions (concepts and descriptions) were taken from a psychology text book on learning and behavior by Mazur (2006) and were slightly modified for the purpose of this study. 